\title{
The Role of Market Research in the Commercialization of Technology
}

\author{
D. L. Ivey
}

S. A. Smith

March 1988

Prepared for the U.S. Department of Energy under Contract DE-AC06-76RLO 1830

Pacific Northwest Laboratory Operated for the U.S. Department of Energy by Battelle Memorial Institute 


\title{
DISCLAIMER
}

This report was prepared as an account of work sponsored by an agency of the United States Government. Neither the United States Government nor any agency thereof, nor Battelle Memorial Institute, nor any or their employees, makes any warranty, expressed or implied, or assumes any legal liability or responsibility for the accuracy, completeness, or usefulness of any information, apparatus, product, or process disclosed, or represents that its use would not infringe privately owned rights. Reference herein to any specific commercial product, process, or service by trade name, trademark, manufacturer, or otherwise does not necessarily constitute or imply its endorsement, recommendation, or favoring by the United States Government or any agency thereof, or Battelle Memorial Institute. The views and opinions of authors expressed herein do not necessarily state or reflect those of the United States Government or any agency thereof, or Battelle Memorial Institute.

\author{
PACIFIC NORTHWEST LABORATORY \\ operated by \\ BATTELLE MEMORIAL INSTITUTE \\ for the \\ UNITED STATES DEPARTMENT OF ENERGY \\ under Contract DE-AC06-76RLO 1830
}

\begin{tabular}{|c|c|}
\hline \multicolumn{2}{|c|}{ Printed in the United States of America } \\
\hline \multicolumn{2}{|c|}{ Available from } \\
\hline \multirow{4}{*}{\multicolumn{2}{|c|}{$\begin{array}{c}\text { National Technical Information Service } \\
\text { United States Department of Commerce } \\
5285 \text { Port Royal Road } \\
\text { Springfield, Virginia } 22161\end{array}$}} \\
\hline & \\
\hline & \\
\hline & \\
\hline \multirow{2}{*}{\multicolumn{2}{|c|}{$\begin{array}{l}\text { NTIS Price Codes } \\
\text { Microfiche A01 }\end{array}$}} \\
\hline & \\
\hline \multicolumn{2}{|c|}{ Printed Copy } \\
\hline & Price \\
\hline Pages & Codes \\
\hline $001-025$ & A02 \\
\hline 026-050 & $\mathrm{A} 03$ \\
\hline 051-075 & A04 \\
\hline 076-100 & A05 \\
\hline $101-125$ & A06 \\
\hline $126-150$ & A07 \\
\hline $151-175$ & $\mathrm{~A} 0 \mathrm{~B}$ \\
\hline $176-200$ & $\mathrm{~A} 09$ \\
\hline 201-225 & A010 \\
\hline 226-250 & A011 \\
\hline $251-275$ & A012 \\
\hline $276-300$ & A013 \\
\hline
\end{tabular}


THE ROLE OF MARKET RESEARCH IN THE COMMERCIALIZATION OF TECHNOLOGY

D. L. Ivey

S. A. Smith

March 1988

Prepared for the U.S. Department of Energy under Contract DE-ACO6-76RLO 1830

Pacific Northwest Laboratory

Richland, Washington 99352 



\section{SUMMARY}

The objective of this report is to provide information on available empirical work that describes criteria used by the residential consumer market in selecting energy and energy-related products. This market is important to the U.S. Department of Energy's (DOE) Office of Building and Community Services (OBCS), which sponsors the development of many energy-conserving technologies ultimately used by the residential consumer. In this report, the consumer decision-making process is described, and case studies are presented to illustrate the importance of conducting systematic market research in the early stages of the technology-development process.

Consumer decision making is examined through a discussion of the steps of the decision-making process: problem recognition, information search, evaluation of alternatives, and purchase decision. Post-purchase behavior and its implications to the OBCS and to commercial marketing research are also discussed.

The four case studies that are presented in this report illustrate the importance of market research in building energy loss, lighting, water heating, and refrigeration:

- Low-Emissivity (low-E) Windows. The guidelines for low-E windows were developed by Lawrence Berkeley Laboratory (LBL) under contract to the DOE, and were accepted by the window industry. A key to this successful transfer was LBL's early market research efforts to determine how the new technology could be used with current window designs, to stimulate interest by presenting information to the key decision-makers, to learn more about low-E experiences in other countries, and to help build industry confidence in the technology.

- Long Life Light Bulbs. The Diolight light bulb is a long-life light bulb invented by Kevin Keating in the late 1970s. This invention marked the beginning of Diolight Technology Incorporated, a company that conducted no systematic market research before producing and attempting to sell their product. Because of this lack of marketing information, potential consumers of the Diolight light bulb viewed it as a high-priced, commonplace item that was produced by an unknown 
company. Eventually, Diolight Technology's unsystematic approaches identified light bulb distributors as the market niche for their light bulb.

- Heat Pump Water Heaters. In the 1970s the Energy Research and Development Agency (ERDA) funded an effort to develop heat pump water heaters to help reduce residential energy consumption. Although the energy crisis of the early 1970s provided a good environment for commercial acceptance, heat pump water heaters did not make an easy transition to the marketplace: no major manufacturers would produce this water heater; original commercial units were sold to the inappropriate distributors; early market estimates were erroneous; and several of the early installations failed to perform adequately. The developers did not realize the price sensitivity of the market or the difficulty of selling a new water heating technology in the replacement market. Marketing efforts that focused on the new construction market would have proven much more successful.

- Energy Efficient Refrigerator-Freezer: In the late 1970s, ERDA sponsored the development of an energy-efficient refrigerator-freezer in the private sector. Arthur D. Little, Inc., in conjunction with Amana, won the contract although neither firm was a major manufacturer of refrigerator-freezers. Amana conducted some marketing and field tests and released the first commercial units in 1981. Although the unit was the most energy-efficient refrigerator-freezer available, it was not commercially successful. The unit's initial cost was significantly greater than that of other refrigerators. Developers were not aware that the most important consumer selection criteria were price, style and need for replacement. Energy efficiency was not viewed as an important criterion in the consumer selection criteria. 


\section{CONTENTS}

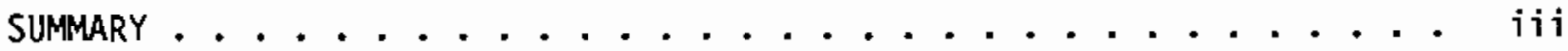

1.0 INTRODUCTION . . . . . . . . . . . . . . . . . 1.1

2.0 CONSUMER DECISION MAKING FOR ENERGY-RELATED INVESTMENTS $\ldots$. . 2.1

2.1 PROBLEM RECOGNITION . . . . . . . . . . . . . . 2.1

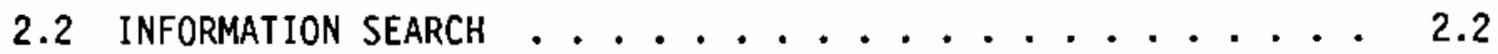

2.3 EVALUATION OF ALternatives . . . . . . . . . . . . . 2.4

2.4 THE PURChASE DECISION . . . . . . . . . . . . . 2.5

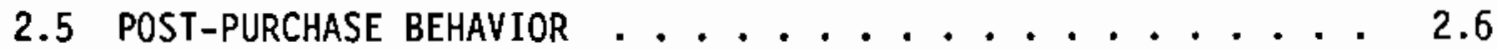

2.6 SUMMARY AND IMPLICATIONS . . . . . . . . . . . . 2.7

3.0 CASE STUdIES . . . . . . . . . . . . . . . . . . . . 3.1

3.1 LOW-E WINDOWS . . . . . . . . . . . . . . . . 3.1

3.2 LONG-LIFE LIGHT BULBS . . . . . . . . . . . . . 3.3

3.3 HEAT PUMP WATER HEATERS . . . . . . . . . . . 3.6

3.4 ENERGY-EFFICIENT REFRIGERATOR-FREEZER . . . . . . . . . 3.9

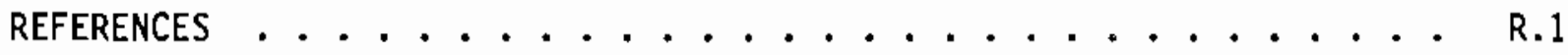





\subsection{INTRODUCTION}

A major market served by the U.S. Department of Energy's (DOE) Office of Building and Community Systems (OBCS) consists of residential end-users of energy and energy-using technologies. Although the residential consumer becomes the ultimate user of the technologies and ideas developed by OBCS, this market segment does not necessarily choose or pay for these technologies. Instead, this function is provided by market intermediaries.

Nevertheless, residential consumers are often the decision makers in replacement or retrofit investment decisions. As the ultimate user of the energy-efficient product, individuals who make up the residential market contribute greatly to public opinion and the acceptance of new technologies. If the residential consumer market does not see a need for a particular technology, it is unlikely that the intermediate market or manufacturers will adopt it. Consequently, it is extremely important for OBCS to understand the residential consumer market to prevent costly research and development errors and to enhance technology transfer/commercialization efforts.

One of the aims of OBCS, in addition to saving energy, is to create benefits to the residential energy user. Understanding the needs, wants, and preferences of this target market is important to designing technologies that can satisfy them. One way to realize the benefits and savings is to examine the consumers' thought processes while making a purchasing decision.

Chapter 2.0 sumnarizes the steps of the process leading to a purchase decision by a consumer. Technology developers must understand this process and the criteria used by consumers to facilitate the transfer of the technology from the laboratory to the marketplace. This understanding of the marketplace is developed by initiating a systematic market research effort early in the technology development process.

Chapter 3.0 presents four case studies of energy conservation technologies that made the transition from the laboratory to the marketplace. An examination of the cases reveals the important role market research can play in the transition. 



\subsection{CONSUMER DECISION MAKING FOR ENERGY-RELATED INVESTMENTS}

Consumers vary in the way they buy a particular product. Consumer purchasing behavior ranges from investing a great deal of time in seeking information and making comparisons, to impulse buying.

A model that demonstrates the stages leading to a purchase decision has been developed and is shown in Figure 2.1. Not all consumers pass through each stage of the model. A buyer making an impulse purchase, for example, may omit several stages and proceed directly to the purchase decision stage. Other reasons that consumers omit some of the stages shown in the model include having enough information about the product, or purchasing a product to alleviate an emergency situation, such as replacing a broken water heater.

\subsection{PROBLEM RECOGNITION}

The buying process begins when the consumer recognizes a problem or need. He recognizes the difference between the state in which he exists and the state in which he wishes to exist. This recognition may be triggered by an internal or an external stimulus. An internal stimulus is a feeling such as hunger or thirst. An external stimulus may be anything external to the consumer, such as an advertisement or a conversation with a friend. For example, a consumer may recognize the need for a new form of heating his home if the present system is not heating the hone to a comfortable temperature (internal stimulus) or his energy bills are too high (external stimulus). If a need that would trigger a consumer's interest in a particular product can be identified, a marketer could use this information to promote the product.

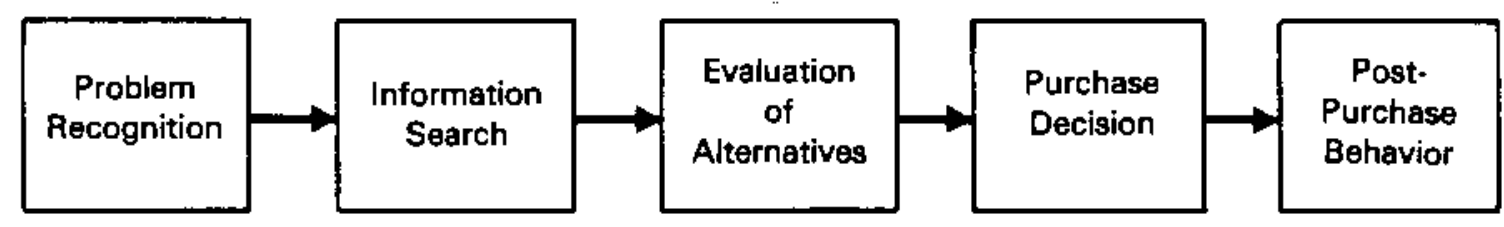

FIGURE 2.1. A Model of Consumer Decision Making 


\subsection{INFORMATION SEARCH}

Once the consumer has recognized a problem or need, he may or may not search for more information, depending on the price of the object, the prior knowledge the consumer brings to the buying situation, the level of involvement the consumer has with the purchase, and the cost (time) of acquiring additional information. Low-involvement purchases, items which are routinely purchased, involve little search activity. A consumer will more likely spend time searching for information in a high-involvement purchase situation.

Assuming that the consumer does undertake an information search, two levels of search behavior are apparent. The first level is called heightened attention, and is a state in which the consumer is more attentive to information concerning the product. For example, if an individual is considering purchasing a heat pump furnace for his home, he may merely become more attentive to advertisements on television and in newspapers about heat pumps. The second level is called an active information search; at this level the consumer looks for reading material and other information concerning the product he is considering purchasing (Kotler 1984). The consumer who considers purchasing a heat pump might read product literature and consumer information guides, talk with neighbors and friends, and visit local distributors.

The major categories of sources for consumer information are shown in Table 2.1. The relative influence of these information sources varies with the product categories and the buyer's characteristics. Generally, most of

\section{TABLE 2.1. Consumer Information Sources}

$\frac{\text { Sources }}{\text { Personal }}$

Conmercial

Public

Experiential
Components

family, friends, neighbors, acquaintances

advertising, salespersons, packaging, in-store displays

mass media nonadvertising, consumer rating organizations

handling, examining, and using the product 
the messages a consumer receives about a product are from comnercial sources. However, the most effective sources tend to be personal (Kotler 1984).

As a result of gathering information, the consumer becomes acquainted with the alternatives available to him. His choice is successively narrowed down in the manner similar to the heat pump example shown in Figure 2.2. This figure uses brands of heat pump furnaces to illustrate the concept of

Level One: Total Set of Brands

Trane, Coleman, Lennox, Nutone, York, General Electric, Heil, Rheem, Carrier, Intertherm, Janitol, etc.

Level Two: Awareness Set

(Brands the consumer is aware of)

Trane, York, Carrier, Coleman, Rheem, Lennox, General Electric

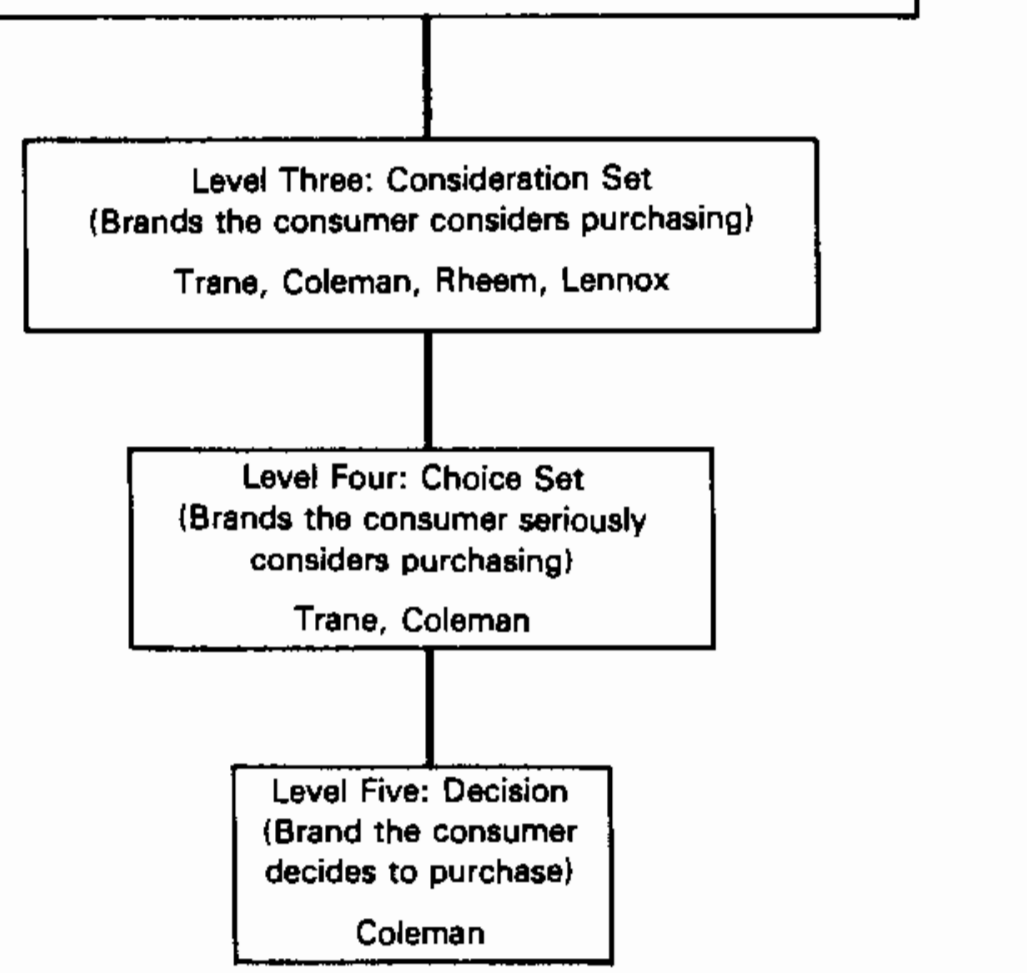

FIGURE 2.2. Successive Levels in Consumer Decision Making 
the steps or sets in consumer decision making. At level one, all the brands of heat pumps available to the consumer are listed. The second level represents a subset of all the brands; this subset consists of the brands the consumer is aware of because of advertising or prior knowledge. The third level is a subset of the brands the consumer is aware of and is considering. The fourth level consists of the brands that have the necessary attributes to be serjously considered by the consumer. At the fifth level, the consumer decides on a particular brand to purchase.

\subsection{EVALUATION OF ALTERNATIVES}

Once a consumer gathers information, he begins to narrow down his alternatives as shown in Figure 2.2. But how does the consumer choose between brands of a product? No one simple evaluation process is used by all consumers, or even by one consumer in all buying situations. Most current models of consumer evaluation processes are based on cognitive theory; in other words, the consumer forms product judgments largely on a conscious and rational basis.

Certain basic concepts help explain the way in which consumers evaluate alternatives. The first of these concepts deals with the specific attributes of the product. For example, a consumer interested in buying a heat pump furnace may be interested in its price, effectiveness, and/or convenience. The consuner will pay attention to those attributes that are related to his needs. The needs or awareness of needs can be stimulated through the technology transfer process, promotional campaigns, or by other commercialization methods. The market for a product can be segmented according to the different perceived needs or product expectations held by different groups of consumers.

In research conducted for the Bonneville Power Administration (BPA), consumers were segmented according to their expectations of several energy conservation measures (Ivey et a1. 1986). In the case of storm windows, the respondents were almost evenly split between expecting monetary and comfort benefits. Following such a study, a marketing campaign could be developed to focus on these two benefits.

A consumer is likely to associate different weights of importance to product attributes relevant to him. If the consumer has financial constraints, 
he may place more importance on the price of a product and less weight on other attributes, such as energy efficiency, reliability, or convenience.

The consumer may also develop a set of brand beliefs about each brand and its relevant attributes. The set of beliefs about a particular brand is called the brand image. This image reflects consumers' perceptions of the brand and is not necessarily based on fact. The consumer will then combine all available information concerning the product and form an opinion about the product alternatives by using an evaluative process.

\subsection{THE PURCHASE DECISION}

Once the consumer evaluates the alternatives and forms preferences, he also forms a purchase intention or a plan to buy a particular brand. Two factors that may intervene between the purchase intention and the actual purchase decision are shown in figure 2.3.

The first of these factors is the attitudes (and opinions) of others. For example, if an influential individual, such as a spouse or close friend, does not agree with the consumer's choice of a coleman heat pump, the consumer may change his mind and choose another brand. The extent to which another person's attitude will alter a preferred choice depends on the intensity of the other person's negative attitude toward the preferred alternative, and the consumer's motivation to comply with the other person's wishes. The more intense the other person's negative feelings and the more important the other person is to the consumer, the more likely the consumer will conform to the other's negative feelings and revise his purchase intentions.

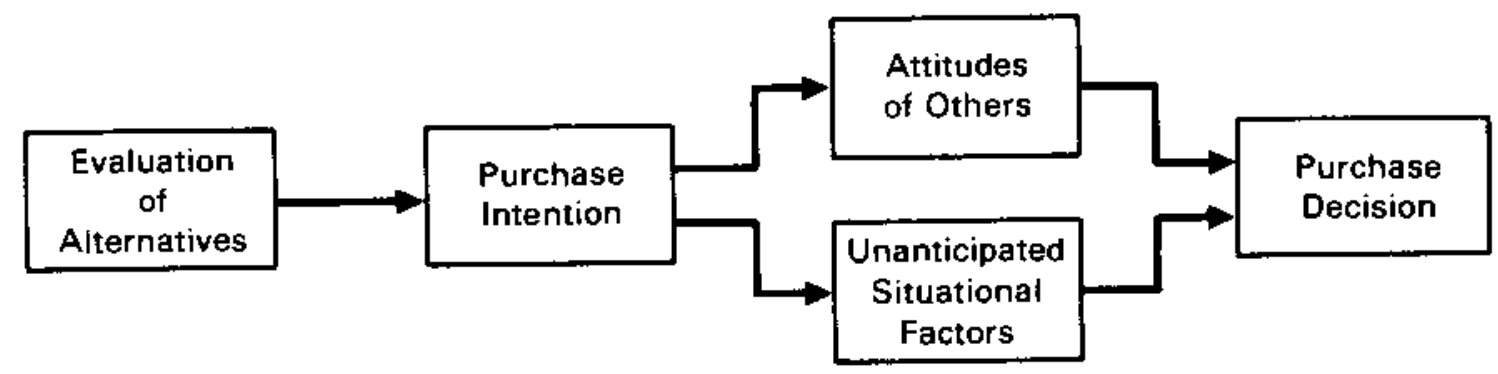

FIGURE 2.3. Steps Between Purchase Intention and Decision 
A second factor influencing purchase intentions is unanticipated situational variables. The consumer forms a purchase intention on the basis of certain factors such as current or expected family income, expected price of the brand, and expected benefits from the product. If the consumer loses his job or the price of a Coleman heat pump increases dramatically (both are examples of unanticipated factors), the purchase intention may be altered.

Once a person has reached a generic purchase decision, there are actually five subdecisions that must be made concerning the purchase:

- brand decision - which brand to purchase

- vendor decision - which store to patronize

- quantity decision - how many of the product to purchase

- timing decision - when to make the purchase

- payment-method decision - how to pay for the purchase. One of the most important subdecisions is how to pay for the purchase: with cash or credit?

In a survey of BPA residential consumers, the results suggested that, given the choice of three different ways to pay for major products, the consumer's first choice was to pay right away with cash (Fang, Hattrup, and Nordi 1986). The second choice was to save for future purchases, and the third choice was to pay by installment, i.e., using a credit card.

\subsection{POST-PURCHASE BEHAVIOR}

After purchasing a product, the consumer will experience levels of satisfaction or dissatisfaction. This level is determined by how closely the product's performance compares with the consumer's prior expectations. If the product matches or exceeds expectations, the consumer will be satisfied and thus, positively reinforced. However, if the product does not meet the consumer expectations, he will experience feelings of dissatisfaction and become negatively reinforced.

The consumer's satisfaction or dissatisfaction with the product will influence his subsequent behavior. If the consumer is satisfied, there is a high probability that he will purchase the same or similar product again. A satisfied consumer will also relay to other consumers the positive qualities 
of the product. A dissatisfied consumer may behave in several different ways depending on the level of dissatisfaction and his individual characteristics. The consumer may take public action, by complaining to the company or filing a lawsuit; private action, by no longer buying the product; or no action at a11. For example, consumers took legal action when a computer model from Wick Building Systems, Inc., predicted energy costs that differed significantly from the owners' actual energy costs (Hendrickson et a1. 1985).

What the consumer ultimately does with the product is a post-purchase behavior that also interests marketers. A consumer may discover a new use for the product that could expand its market potential. In this case feedback from ultimate consumers is quite important.

\subsection{SUMMARY AND IMPLICATIONS}

It is important for the OBCS to understand the decision-making processes of residential consumers. The OBCS can better develop successful commercialization/transfer strategies by exanining at which stage of the decision-making process potential consumers appear to be. For example, if the majority of OBCS's target market for a heat pump furnace just now recognizes that a need exists because their homes are not heated comfortably, or their energy bills are too high, OBCS can provide information about this realization to dealers and other intermediaries who, in turn, would use the information to sell the

heat pump furnace. Once the consumer is aware of the benefits of a product and how it fills an apparent need, various strategies may be employed to induce the consumer to utilize the technology.

It is important, however, to make the consumer aware of the benefits of utilizing the technology before persuading him to buy it. Otherwise, a vital step in the decision-making process will have been neglected. Neglecting this step may result in confused consumers who are not likely to purchase the advertised product or who will become negatively reinforced after the purchase. 



\subsection{CASE STUDIES}

This section reviews the development of four energy conservation technologies from conceptualization to commercialization. The important role that market research can play in the successful commercialization of a technology can be seen in these cases. The technologies reviewed are lowemissivity (low-E) windows, long-life light bulbs, heat pump water heaters, and high-efficiency refrigerator-freezers.

\subsection{LOW-E WINDOWS}

According to the American Council for an Energy-Efficient Economy (1986), one quarter of all the energy used to heat and cool U.S. buildings is required to compensate for unwanted heat flow through windows. As a result of the energy crisis in the late 1970s, new building energy guidelines were developed that required greater use of double glazing and a reduction in overall window area. In 1976, as a result of these new building energy guidelines, the DOE initiated a program at Lawrence Berkeley Laboratory (LBL) to develop guidelines for a more efficient use of windows and to develop more energy-efficient window components and window systems.

At DOE's direction, researchers at $L B L$ undertook the development of a window coating that was transparent to visible light and solar radiation but reduced heat flow or energy loss. This principle is known as low-E. With DOE funding, the LBL issued grants to several small research firms in 1976 with the intent to investigate potential coating systems and deposition processes for low-E films.

Also during this time, researchers from LBL held extensive conversations and meetings with key personnel in the window industry to discuss the new low-E technology and to decide how the technology could be best used with current and proposed window designs. A limited number of market research studies were also conducted. The researchers also presented the benefits of this new technology, as uncovered in building simulation studies, to architects and engineers to try to build market interest and demand for the products. 
Early research efforts were concentrated on reviewing various deposition processes to determine if any had the potential to deposit the types of materials required for low-E coatings at high deposition rates and with good uniformity. One process known as magnetron sputtering, which was designed by Airco Solar Products, appeared to have this potential. Originally this process was designed to produce solar control coatings for architectural applications. However, based on the initial results from DOE-sponsored studies, Airco invested research and development (R\&D) monies into developing low-E coatings that could be used with its magnetron sputtering process. This investment was necessary because most of the U.S. glass companies did not have the resources to invest in this type of R\&D effort, and none had deposition systems capable of producing the coatings.

Low-E coatings were first successfully commercially marketed in Europe. This success was apparently related to the relatively high energy prices, more restrictive building standards, and a long-standing tradition of greater first-cost investment in buildings in Europe (Anerican Council for an EnergyEfficient Economy, 1986). Airco sold one of its first sputtering magnetron machines to a company in the United Kingdom; the machine was installed in Sweden later. Following this introduction, LBL researchers participated in an International Energy Agency Task Group on window performance with researchers from several European countries. This participation provided LBL researchers with an opportunity to learn more about the experiences with low-E in other countries and to share those insights with the U.S. industry.

In order to disseminate the European findings as well as the research being conducted in the United States, and to build confidence in low-E technology in the early 1980s, LBL researchers gave presentations at industry association meetings and trade shows, and met privately with research and marketing staff from a number of major window manufacturers. The LBL researchers also developed new tables of heat transfer data for low-E windows which were published in the 1985 ASHRAE Handbook - Fundamentals (1985).

In 1983, an important breakthrough occurred when Airco installed a sputtering plant for low-E coatings for Cardinal IG, the firm that supplies the sealed insulating glass units for the Anderson Corporation, the largest 
window manufacturer in the United States. Once Anderson announced the availability of a low-E window, the product gained new credibility in the eyes of consumers, builders and specifiers, and it placed additional competitive pressure on other window manufacturers. Sales figures indicate that by 1985, approximately $5 \%$ of the window market had been captured. By the mid-1980s almost every major glass and window company offered a low-E product.

Currently glass and window companies can offer a variety of low-E products that include sputter coating on glass, coated plastic films, and pyrolytic hard coats. The pyrolytic low-E hard coats can be used on single glazing and nonsealed multiple glazing units which will help expand sales in the retrofitting market. Market researchers at Pittsburgh Plating and Glass (PPG), a major U.S. glass manufacturer, believe that the pyrolytic low-E hard coatings will help low-E products penetrate up to a third of the residential market by 1994.

This energy-conserving technology illustrates the success that can be achieved through public-private partnerships. Without the initial funds spent by DOE, it may have been years before the glass industry would have invested R\&D funds into such a potentially high-risk technology.

The future market potential for low-E products is very promising. An estimated 70 million $\mathrm{ft}^{2}$ of low-E windows were sold in the United States in 1985. Research is continuing to improve the optical and themal properties of low-E products. Initial cost of low-E products should also decrease once market penetration increases. In the residential sector, windows with low-E coatings are now specified for new construction, additions and renovations. The current residential market for all types of windows is approximately 700 million $\mathrm{ft}^{2}$.

\subsection{LONG-LIFE LIGHT BULBS}

Market research can help eliminate many of the pitfalls suffered by many companies attempting to transfer new technology from the laboratory to the marketplace. The case of the Diolight light bulb is an excellent example of 
the barriers encountered in attempting to introduce a new technology before establishing a clear understanding of the market.

In the late 1970s, Kevin Keating had an idea for extending the life of an incandescent light bulb; he incorporated a voltage-reducing diode into a fairly standard bulb. The resulting Diolight bulb had the ability to burn continuously for an average of about 82 months versus an average of about 6 months for a standard bulb. The voltage-reducing diode technology was the basis for establishing the company, Diolight Technology Incorporated, and its founders expected that their technology alone would al low them to capture a significant portion of the $\$ 2$ billion light bulb market. The major competitors at that time were General Electric, Sylvania, and Philips; these three companies controlled approximately $90 \%$ of the market.

Diolight Technology encountered immediate resistance when they tried to find a light bulb manufacturer to produce their bulb. Major light bulb producers were not willing to make a product that would be in direct competition with their own products. Eventually Diolight found a Taiwanese company to manufacture the Diolight bulb.

The original Diolight bulb was tubular-shaped and designed for use in building EXIT signs. Unfortunately, none of the Diolight staff had any idea of the potential size of the EXIT sign market. This lack of information made production planning difficult. The Diolight staff attempted to estimate the size of market by visiting several comnercial buildings in the Detroit, Michigan, area, counting the number of EXIT signs on one floor, then multiplying by the number of floors in the building. Based on this procedure, the staff estimated the number of EXIT signs in the United States to be 40 to 60 million. The Diolight staff decided to have the Taiwanese manufacturer produce 15,000 bulbs.

Diolight Technology was fairly confident that they would capture a significant share of the market since their light bulb would save money. Diolight's initial sales force consisted of one staff member who canvassed bars, restaurants, and commercial buildings in the Detroit area. Potential 
customers were not interested in paying a relatively high price for a commonplace item sold by an unknown company. Only 1200 bulbs were sold in this initial sales effort.

As a part of their next sales effort, Diolight employed college graduates to canvass corporate purchasing agents by telephone. The Diolight sales representative then made follow-up visits to the agents contacted by telephone. Diolight encountered the same resistance with the new strategy as they had faced in the past. Corporate purchasing agents were not interested in buying a relatively high-priced light bulb from an unknown company. Sales of the Diolight bulb remained low.

In desperation, the Diolight staff used the telephone book to compile a list of 15 light bulb distributors. The sales staff then met with each of the distributors, explained the technology, and described what the company felt would be the best markets for their bulb. These markets included any organization having light fixtures where changing a bulb would be extremely difficult and/or costly, or where aesthetics was important and a burned-out bulb would detract from the appearance (such as chandeliers and signs). Although they sold standard-life bulbs for the three major producers, several distributors agreed to sell the Diolight bulbs. By June 1984 about 40,000 bulbs were sold per month.

The company also began distributing press releases to radio stations, local newspapers, and trade publications. Many of the press releases prompted interviews and feature articles describing the technology and the company. Sales grew as a result of this publicity, and bulb distributors began to call Diolight for more information on becoming a company distributor. Currently the company has 125 distributors covering al1 50 states with annual sales of $\$ 800 \mathrm{~K}$.

The staff at Diolight was development-oriented and was not aware of the information needed before they could begin to transfer their long-life light bulb from their laboratory to the marketplace. The Diolight staff was surprised by the initial market reluctance in accepting their product.

Had a systematic market research effort been initiated simultaneously to the development of the light bulb, the barriers to Diolight's introduction 
into the marketplace would have been jdentified and reduced. Specifically, this effort would have helped identify the unique market niche for the technology--the costly and aesthetic lighting segment. A more accurate estimate could have been made of potential size of this niche and aided their production planning. The market research effort would have identified the most appropriate and effective channels of bulb distribution--selling through bulb distributors instead of directly to the end-user. This work would have also helped to identify the decision criteria used by end-users, namely price and manufacturer credibility.

\subsection{HEAT PUMP WATER HEATERS}

According to a recent report published by the Electric Power Research Institute (Nesbit 1984), water heating accounts for approximately one-fifth of the energy used in a typical household. Fifty-three percent of households use in-place water heaters fueled by natural gas, and another 45\% of households use electric resistance water heating. Propane, oil, solar units, and heat pump water heaters (HPWHS) account for the remaining $2 \%$ of the market. The HPWHs are considered energy efficient because they use $50 \%$ or less of the energy used by an electric resistance water heater.

The principle of HPWHs is not new. The concept has been understood for over a century and applicable patents date back to the 1930 s. The Hotpoint Co. (now the Hotpoint Division of the General Electric Co.) developed the first HPWH designed for commercialization in the 1950s. Apparently the HPWH itself worked well, but it did not succeed in the water heater market. Its failure was attributed to low electricity rates, the high cost of the units themselves, and a lack of consumer interest.

In the 1970s, interest in HPWHs was renewed as energy prices began to rise and the potential of heat pumps to conserve energy was recognized. In 1976, Robert Dunning, the president of Energy Uti]ization Systems, Inc. (EUS), approached the Energy Research and Development Administration (ERDA, the predecessor of DOE) with a proposal to develop a residential-scale HPWH. The ERDA was interested in the HPWH, but not in EUS, a small consulting firm. 
The ERDA wanted rapid comercialization and believed that a large manufacturer had to be involved to successfulily bring the HPWH onto the market.

EUS then approached the National Rural Electric Cooperative Association (NRECA). The NRECA gave EUS a \$5,000 grant to produce a prototype HPWH, which was displayed in February 1977 at the NRECA Annual Meeting. At about the same time, ERDA directed Oak Ridge National Laboratory (ORNL) to send out a request for proposal (RFP) on the development and commercialization of highly efficient water heating systems. The RFPs were sent to water heater manufacturers and nonmanufacturers; however, ORNL recomended that proposals from nonmanufacturers show a link to a manufacturer to facilitate product comercialization. No proposals were received from water heater manufacturers. EUS submitted a proposal that designated Mor-Flo Industries, one of the nine major water heater manufacturers in the United States, as the provider of the water tanks and the shipping cases. EUS was awarded the contract.

The EUS project had two phases. In Phase I, EUS developed two HPWH versions--an "integral" model (the heat pump and tank are combined in one device) and a "retrofit" model (a separate heat pump package that connects to an existing water tank)--and conducted a market study to determine the potential demand for each. In Phase II, EUS manufactured 225 demonstration units and used half of these in a field test; it also assessed the lifetime performance of the integral HPWH. Although, the retrofit HPWH model was not successful, the integral model was considered a success. The testing revealed an average HPWH operating-cost savings of $48 \%$ over electric resistance water heating. A consumer attitude survey, conducted during the field test, showed that the vast majority of users participating in the study were satisfied with the operation of the HPWHs.

At about the same time, other companies, such as E-Tech and Fedders, began to develop HPWHs. Before the end of Phase II, EUS made arrangenents for the commercialization of the integral HPWH. The units were sold primarily to plumbing supply distributors, who in turn sold the units to plumbers and water heater dealers. This distribution strategy was not 
successful, and the installed cost to the consumer was usually higher than the $\$ 800$ or $\$ 900$ figure quoted in the promotional literature.

Fedders and E-Tech had already begun marketing their units before EUS introduced its HPWH into the comnercial market. Shortly after EUS entered the market, several other companies also introduced a HPWH. The companies included Carrier, Rheem-Rudd, Duo-Therm, DEC International, and several smaller companies. These companies experienced pricing and distribution problems similar to those encountered by EUS.

Currently, E-Tech, EUS, and Duo-Therm are the industry leaders. E-Tech has an estimated $40 \%$ of all HPWH sales, while EUS and Duo-Therm have an estimated market share of $20 \%$ to $25 \%$. Current total residential sales are estimated at between 7000 and 9000 units a year, less than $0.1 \%$ of the total water heater sales in the United States.

In retrospect, EUS and the other HPWH manufacturers failed to realize that the high first cost and relative technical sophistication of HPWHs made them almost impossible to sell in the replacement market, and very timeconsuming and expensive to sell in the retrofit markets. Most of the replacement market for water heaters is not accessible to HPWHs because replacement sales generally occur when the existing water heater fails and must be replaced quickly. The primary sales information is presented by the service representative, who is called to repair the failed unit, and who may have very limited knowledge about the HPWH. Furthermore, the need for an immediate replacement works against the expensive HPWH because there is no time to arrange financing for the purchase.

The greatest marketing success was achieved in the retrofit and new market areas by face-to-face sales presentations, especially when accompanied with a demonstration of the technology. Some E-Tech dealers took a small model of the HPWH in the back of their car for 30-minute demonstrations. Greater success may be achieved by HPWH manufacturers in the market for new sales. The market for new sales includes intermediaries such as home builders and developers, who are easier to identify and sell to than are individual homeowners. It is difficult to target marketing efforts to 
individual homeowners since distributors do not readily know whether homes are set up for gas-fired water heating or for electric water heating.

EUS and the other manufacturers have now begun to support specialized dealers who are solely responsible for installing and servicing their HPWHs. Most of these dealers are tied to the products of a specific manufacturer and receive training, certification, and sometimes, financial support. EUS is also exploring the possibility of relying on utilities to actively market HPWH units in their service areas.

The future for HPWHs remains somewhat uncertain. Sale of major household appliances tends to track the building industry. (a) The HPWH was introduced comnercially in the early 1980s, about the same time the housing market began to slow down. In response, builders installed conventional water heaters, a lower capital cost option. The initial high cost of the HPWH as well as the relatively low energy costs in the United States will remain major impediments to its market penetration.

\subsection{ENERGY-EFFICIENT REFRIGERATOR-FREEZER}

In 1977. Thermo Electron conducted a study to identify those appliances that offered the greatest potential for energy savings (Hurley 1978). Refrigeration and water heating were found to be the two appliance technologies with the largest potential for energy savings. In 1976, as part of an effort to develop and comnercialize energy-efficient appliances, the ERDA directed ORNL to release an RFP soliciting proposals from the private sector for the development and comnercialization of an energy-efficient, automatic, residential refrigerator-freezer.

Arthur D. Little, Inc. (ADL), in conjunction with Amana, won the contract and began work in June 1977. The first tasks included determining the characteristics of the targeted market for the high-efficiency refrigerator-freezer unit and identifying and ranking potential energy-saving options that would be included in the refrigerator. They decided to focus on

(a) Personal communication with a senior engineer at Science Applications, Inc., San Diego, California. 
the 16-ft 3 autonatic defrost refrigerator-freezer. Eighteen energy-saving options were examined. The options were evaluated using ADL's simulation mode1, which generated a rating factor combining the impact of energy savings, noise, change in unit size, and life cycle costs. The seven options selected were

- an optimized insulation design

- a static back-mounted condenser

- a standard forced convection freezer evaporator

- a free convection refrigerator evaporator in series with the freezer evaporator--for off-cycle self-defrost

- a new fan/air flow path design

- a reduced defrost frequency

- double gaskets to seal doors.

A prototype was designed and tested during 1977 and 1978. In 1979, after the successful completion of the prototype tests, Amana decided to proceed with a pilot production run. A marketing/field test program to assess the unit's consumer appeal and its in-home performance was also conducted. The units sold in the pilot production run were sold through a "simulated" sales program which emphasized the frost-free freezer feature and the moist-cold refrigerator compartment which minimizes food dehydration.

After conducting marketing and field tests, Amana decided to go into comanercial production of an $18 \mathrm{ft}^{3}$ refrigerator-freezer in 1981. In 1983, the Association of Home Appliance Manufacturers (AHAM) directory of Certified Refrigerators and Freezers listed the Amana refrigerator-freezer as a system with a total refrigerated volume of $18 \mathrm{ft}^{3}$ and an annual energy cost of $\$ 43$. At this level of performance, the Amana refrigerator-freezer was the most energy-efficient of the top freezer, automatic defrost refrigerators in the 16.5- to 18.4- $\mathrm{ft}^{3}$ range. In 1983, the Anana refrigerator cost between $\$ 689$ and $\$ 999$. This was about $\$ 200$ more than the average refrigerator and almost $\$ 150$ to $\$ 170$ more than the next two most energy-efficient models on the market in 1982. 
Several consumer surveys of refrigerator buyers conducted between 1978 and 1983 indicated that the three most important features influencing the purchasing decision for refrigerators were price, style/design, and need for replacement (Appliance Manufacturers, 1978-1983). Energy efficiency was found to be important only between 1980 and 1981 and only in combination with the three other features. Even when consumers were sensitive to energy efficiency in 1980 and 1981, they would rather purchase a refrigeratorfreezer with the desired features and a lower rate of energy efficiency than a highly energy-efficient appliance with fewer of the desirable features.

These surveys mirrored the consumer reaction to the Amana's energy efficient refrigerator-freezer. After only a few months, Amana discontinued production of this model. In a January 1983 Consumer Reports review of refrigerator-freezers, the major problems of the Anana model were cited:

- Operation. Once it was comnercialized, the refrigerator did not operate as well as expected.

- Cost. The Amana model cost $15 \%$ more that the second highestpriced refrigerator on the market and 246 more than the average price of the 12 refrigerators reviewed.

Consumer Reports suggested the reasons for the high cost:

- the unit was more expensive to produce and production costs had to be recovered

- the investment in tooling had to be recovered

- the model was the most energy-efficient on the market.

Although Amana conducted some marketing and field tests, the developers of this energy-efficient refrigerator-freezer were not sensitive enough to the fact that the most important consumer selection criteria were price, style, and need for replacement. When purchasing refrigerator-freezers, energy efficiency was not an important consumer selection criterion.

In 1983 Amana offered a new line of energy-efficient refrigeratorfreezers that were priced approximately $\$ 120$ less than the high 
energy-efficient refrigerator-freezer that was offered in 1982. These new refrigerator-freezers were developed using the same ADL computer model used previously.

This energy-efficient refrigerator-freezer could be considered a success in terms of its research and development efforts. It was the most energyefficient model commercially available to consumers. However, the product was not a success commercially because it was priced too high. Potential customers could not justify Amana's higher price in terms of the energy savings the unit offered and of the products sold by competitors. This project helps to illustrate the importance of using the findings from market research studies. 


\section{REFERENCES}

American Council for an Energy-Efficient Economy. 1986. Federal R\&D on Energy Efficiency A $\$ 50$ Billion Contribution to the U.S. Economy. A white Paper on the Consequences of Proposed FY 1987 Budget Cuts. 1001 Connecticut Ave., NW, Suite 535, Washington, D.C. 20036.

Appliance Manufacturers. April 1978 through 1983; October 1978 through 1983.

American Society of Heating, Refrigerating, and Air Conditioning Engineers, Inc. 1981. ASHRAE Handbook of Fundamentals. Atlanta, Georgia.

"Refrigerator/Freezers." January 1983. Consumer Reports.

Nesbit, W. 1984. "Pumping Heat Into Cold Water." EPRI Journal 9(1):16-21. Electric Power Research Institute, Palo Alto, California 94303.

Fang, J. M., M. P. Hattrup, and R. T. Nordi 1986. Financing Residential Energy Conservation Investment in the Northwest, 1985. PNL-5905. Pacific Northwest Laboratory, Richland, Washington.

Hendrickson, P. L., B. L. Mohler, Z. T. Taylor, A. D. Lee, and S. A. Onisko. 1985. Marketing Energy Conservation Options to Northwest Manufactured Home Buyers. PNL-5496 (Rev. 1), Pacific Northwest Laboratory, Richland, Washington.

Hurley, J. R. 1978. Energy Conservation Opportunities in Commercial Appliances. ORNL 7261/1, prepared for Oak Ridge National Laboratory, Oak Ridge, Tennessee, by Thermo Electron, 101 First Avenue, Waltham, Massachusetts 02254 .

Ivey, D. L., B. M. Bailey, M. P. Hattrup, R. T. Nordi, S. A. Shankle. 1986. 1985 Consumer Segmentation: Assessment of the Market for Conservation in the Northwest: Phase II. PNL-6111, Pacific Northwest Laboratory, Richland, Washington.

Kot ler, P. 1984. Marketing Management: Analysis, Planning and Control. 5th edition. Prentice-Hall, Inc., Englewood Cliffs, New Jersey. 
$\checkmark$ 


\section{DISTRIBUTION}

No. of

Copies

OFFSITE

50 F. Abe ]

Office of Building and

Cormunity Services

U.S. Department of Energy

Washington, D.C.

W. J. Raup

Office of State and Local Assistance Program

U.S. Department of Energy

Washington, D.C.

10 DOE/Office of Scientific and Technical Information

5 M. Brown

Oak Ridge National Laboratory

P.0. Box $X$

Oak Ridge, TN 37831

B. C. Farhar

Solar Energy Research Institute

1617 Cole Bivd.

Golden, CO 80401

D. Ivey

15273 6th Ave. N.E.

Seattle, WA 98125

R. Kanter

Oak Ridge National Laboratory

P.0. Box $X$

Oak Ridge, TN 37831
No. of

Copies

J. LaMontagne

Brookhaven National Laboratory

Upton, NY 11973

5. Suell

Oak Ridge National Laboratory

P.0. Box $X$

0ak Ridge, TN 37831

ONSITE

DOE Richland Operations Office

J. J. Sutey

20 Pacific Northwest Laboratory

M. R. Anderson

C. L. Bruneau

R. L. Eckert

S. A. Harkreader

M. P. Hattrup

B. F. Roberson

T. J. Secrest

S. A. Smith

R. 0. Weijo (5)

Publishing Coordination MH (2)

Technical Report Files (5) 
